\title{
3.2-3.0Ga Sm-Nd age of gabbro- anorthositic rocks from the Nuasahi and Mayurbhanj Complexes (eastern India): Major mafic magmatic event in the Singhbhum Craton and associated $\mathrm{Ni}-\mathrm{Cu}$-(PGE) sulphide mineralization
}

\author{
SISIR K. MONDAL ${ }^{1}$, MS. CHIRASREE BHATTACHARJEE, \\ DOING PH.D ${ }^{1}$ AND LAURIE REISBERG ${ }^{2}$ \\ ${ }^{1}$ Jadavpur University \\ ${ }^{2}$ Université de Lorraine, CNRS, CRPG \\ Presenting Author: sisir.mondal@gmail.com
}

The Nuasahi and Mayurbhanj Complexes and related magmatic ore deposits (e.g., chromite, magnetite, Ni-Cu-(PGE) sulphides) were formed during major ultramafic-mafic magmatic activity in the Singhbhum Craton in eastern India. The Nuasahi Complex is characterized by a lower ultramafic unit that includes three chromitite ore bands within serpentinized dunite, and a PGE-rich breccia zone that occurs in the lower part of the upper gabbro overlying the ultramafic unit. The breccia zone contains $\mathrm{Ni}-\mathrm{Cu}-(\mathrm{PGE})$ sulfide rich chromitite breccia with high $\mathrm{Pd}$ concentrations. The magnetitite band in the upper part of the Nuasahi gabbro is also Pd-rich and is associated with minor sulphides. In contrast, the magnetitite band in the Mayurbhanj Complex is devoid of any sulphide minerals but the lower gabbro-noritic unit contains a pyrite-dominated sulphide mineral assemblage with accessory magnetite. A Sm-Nd whole-rock errorchron for the upper gabbroic-anorthosites of the Mayurbhanj Complex yielded an age of $3022 \pm 180 \mathrm{Ma}(\mathrm{MSWD}=72)$ with an initial ${ }^{143} \mathrm{Nd} /{ }^{144} \mathrm{Nd}=0.50849 \pm 0.00017$. This corresponds to an $\varepsilon_{\mathrm{Nd}(\mathrm{o})}$ value of $-4.4 \pm 3.3$, suggesting possible derivation from an enriched or crustily contaminated source. When samples of the lower gabbro-norites are included with the upper gabbroicanorthosites from the Mayurbhanj Complex the quality of the correlation is degraded, suggesting that the lower gabbro-norites have been perturbed. The gabbroic samples of the Nuasahi Complex also yield a poorly defined correlation line with a corresponding age of $\sim 3300 \mathrm{Ma}$ with a large error. If all samples of this study from both the Nuasahi and Mayurbhanj Complexes are included in the $\mathrm{Sm} / \mathrm{Nd}$ diagram, a line with an age of $3208 \pm$ $270 \mathrm{Ma}$ is obtained. Though poorly constrained, the similarity between the Sm-Nd ages of the two igneous complexes signifies a large-scale mafic magmatic event in the Singhbhum Craton in the Mesoarchean era $(3200-2800 \mathrm{Ma})$, contemporaneous with similar mafic activity occuring elsewhere in Indian and worldwide ancient cratons. Significant magmatic ore deposits in association with ultramafic-mafic magmatism are present globally during this particular era, and recognition of the similar timing of the magmatic event enhances the exploration potential of these rocks in the Singhbhum Craton. 